Celebes Abdimas: Jurnal Pengabdian Kepada Masyarakat

http://journal.lldikti9.id/CER/index

Vol 2, No, 1, April 2020, pp 07-15

p-ISSN:2656-7938 dan e-ISSN: 2657-1870

DOI: https://doi.org/10.37541/celebesabdimas.v2i1.358

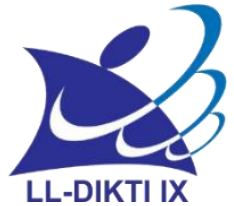

\title{
Pembentukan Kelompok Pendukung Asi (Kp-Asi) Tingkatkan Cakupan Asi dan Mpasi
}

\author{
Rohmayanti', Margono ${ }^{2}$, Herma Fanani Agusta ${ }^{3}$, Wina Amelia Rinjaniं, Nikita Cahyani ${ }^{5}$, \\ Titi Wijayanti 6 , Yunia Luthfi Rana ${ }^{7}$ \\ 12 Ilmu Keperawatan, Fakultas Ilmu Kesehatan UM Magelang, Indonesia \\ 3Ilmu Farmasi, Fakultas Ilmu Kesehatan UM Magelang, Indonesia \\ 45 Ilmu Keperawatan, Fakultas Ilmu Kesehatan UM Magelang, Indonesia \\ 67 Ilmu Farmasi, Fakultas Ilmu Kesehatan UM Magelang, Indonesia \\ 1Email: rohmayanti@ummgl.ac.id
}

\section{Artikel info}

\section{Article history:}

Received: Maret-2020

Revised: Maret-2020

Accepted: April-2020

Publish: April-2020
Abstract. The purpose of community service (PPMT) is to form a breastfeeding support group (KP-ASI) consisting of health cadres and supported by the head of village and midwives of health center so as to improve the coverage of exclusive and a food making skills for escort or MP-ASI, in addition to this activity, aims to hone the skills of students in the Community service program. Implementation method with participatory community empowerment through Apraissal Participatory Rural model is approach in the process of empowerment and improvement of community participation, activities conducted in the form of socialization of activities on all elements of the village related, the establishment of the structure of KP-ASI, lactation management training, assistance cadres practice management skills of lactation in Posyandu, training of MP-ASI skills, guidance of cadres in Posyandu practice of MP-ASI skills, evaluation or monitoring of activities through the lactation management competition and MPASI between cadres as a form of evaluation. The results of this activity in the form of the structure of KP-ASI organization with SK from the village head, there is an increase in the knowledge and skills of cadres in the management of lactation and MP-ASI. The test result of pre posttest in the test with value $P=0.00(<0.05)$ indicates that the knowledge of participants significantly increased. The results of the competition between cadres in the presentation of MP-ASI show the result that cadres can properly prepare MP-ASI. Data from village Midwives stated that there was an increase in BREAST feeding and MP-ASI in Sidoagung Tempuran village.

Abstrak. Tujuan Pengabdian Pada Masyarakat Terpadu (PPMT) ini adalah untuk membentuk Kelompok Pendukung ASI (KP-ASI) yang terdiri dari kader Posyandu dan didukung oleh Kepala Desa serta Bidan Puskesmas sehingga mampu meningkatkan cakupan ASI Eksklusif dan Keterampilan Pembuatan Makanan Pendamping ASI atau MP-ASI, selain itu kegiatan ini bertujuan mengasah 
kemampuan mahasiswa dalam program pengabdian masyarakat. Metode pelaksanaan dengan pemberdayaan masyarakat partisipatif melalui model Participatory Rural Apraissal berupa pendekatan dalam proses pemberdayaan dan peningkatan partisipasi masyarakat, Kegiatan yang dilakukan berupa sosialisasi kegiatan pada seluruh unsur desa yang terkait, pembentukan struktur KP-ASI, pelatihan Manajemen Laktasi, pendampingan kader praktek keterampilan manajemen laktasi di Posyandu, pelatihan keterampilan MP-ASI, pendampingan kader di Posyandu praktek keterampilan MP-ASI, evaluasi atau monitoring kegiatan melalui lomba manajemen laktasi dan MP-ASI antar kader sebagai bentuk evaluasi. Hasil kegiatan ini berupa terbentuknya struktur organisasi KP-ASI dengan SK dari Kepala Desa, terdapat peningkatan pengetahuan dan keterampilan kader dalam manajemen laktasi dan MP-ASI. Hasil Uji Pre posttest di uji dengan nilai $p=0,00(<0,05)$ menunjukkan bahwa pengetahuan peserta signifikan meningkat. Hasil lomba antar kader dalam penyajian MP-ASI menunjukkan hasil bahwa kader dapat menyiapkan MPASI dengan benar. Data dari bidan desa menyatakan bahwa terjadi peningkatan cakupan pemberian ASI dan MP-ASI di Desa Sidoagung Tempuran.

Keywords:

KP-ASI; ASI

Eksklusif; MP-ASI;
Coresponden author:

Rohmayanti

Prodi D3 Keperawatan, Fakultas Ilmu Kesehatan, UMMagelang Email: rohmayanti@ummgl.ac.id

artikel dengan akses terbuka dibawah lisensi CC BY -4.0

\section{PENDAHULUAN}

Desa Sidoagung merupakan desa yang terletak di Kecamatan Tempuran Kabupaten Magelang, terdiri dari 12 dusun yang terdapat diantaranya beberapa pabrik tekstil dan pabrik pakan ternak sehingga mayoritas wanita bekerja di pabrik dan menjadi buruh harian lepas, wiraswasta seperti tukang cukur, tukang jahit, dan tukang las, sisanya bekerja sebagai buruh tani. Sumber daya yang sudah dimiliki desa tersebut yaitu pengembangan PAUD dengan program pendidikan, terdapat 12 posyandu di setiap dusun program kesehatan. Selama ini kegiatan posyandu di Desa Sidoagung. Dengan adanya posyandu di berbagai dusun di Desa Sidoagung maka akan dikembangkan program kesehatan ibu dan anak serta dibuatnya kelompok pendukung ASI agar wanita yang mayoritas bekerja di desa tersebut dapat memberikan ASI ekslusif kepada bayi berumur 0-6 bulan dan pembuatan MP-ASI untuk mendukung pemberian setelah ASI kepada bayi usia 6-12 bulan.

ASI ekslusif merupakan pemberian nutrisi paling baik pada bayi sejak kelahiran hingga 6 bulan tanpa diberikan makanan pendamping seperti bubur maupun susu formula. ASI sangat bermanfaat untuk bayi selain sebagai sumber tenaga bagi bayi, ASI juga dapat meringankan pencernaan, meningkatkan kekebalan tubuh, dapat mengurangi resiko angka kurang gizi serta gizi buruk pada bayi dan dapat mengurangi resiko obesitas (kegemukan). Selain dapat bermanfaat bagi bayi sang ibu juga diuntungkan dari segi ekonomi karena tidak perlu memberikan susu formula, tahun lama basi, dan praktis, mengurangi berat badan sang ibu dan mengurangi resiko kanker payudara (Nurlaila. 2019).

Berdasarkan SDKI 2012 menunjukan bahwa 71,5 \% anak usia 6-24 bulan mendapatkan makanan dari sayuran dan buah yang kaya vitamin A dan sebesar 37 persen diberi makan sesuai dengan semua praktik IYCF (infant and young child feeding practice) yang direkomendasikan 
(produk susu atau susu, dengan keragaman yang memadai dan frekuensi makan). Hal ini menunjukan bahwa masih ada anak yang belum mendapatkan makanan yang kaya akan vitamin A dan pemberian MP-ASI yang belum sesuai standar WHO (Rinata, Hanum, and Rusdyati 2016).

Pemberian makananan pendamping ASI (MP-ASI) usia 6-12 bulan seringkali menjadi suatu hal yang merepotkan bagi keluarga, umumnya keluarga memilih makanan cepat saji, sementara memasak sendiri perlu waktu yang lebih lama, hal ini juga terjadi pada masyarakat di Desa Sidoagung. Situasi seperti ini merupakan peluang untuk memunculkan kreativitas yang bernilai ekonomi dengan penyediaan makanan pendamping ASI yang higienis, bernilai gizi baik dengan kemasan yang menarik. Banyak hal yang telah dilakukan pemerintah dalam upaya peningkatan pemberian ASI eksklusif diantaranya adalah sarana pelayanan kesehatan mempunyai kebijakan Peningkatan Pemberian Air Susu Ibu (PP-ASI) tertulis yang secara rutin dikomunikasikan kepada semua petugas, melakukan pelatihan bagi petugas dalam hal pengetahuan dan keterampilan untuk menerapkan kebijakan tersebut, menjelaskan kepada semua ibu hamil tentang manfaat menyusui dan penatalaksanaannya dimulai sejak masa kehamilan, masa bayi lahir sampai umur 2 tahun termasuk cara mengatasi kesulitan menyusui, membantu ibu mulai menyusui bayinya dalam 30 menit setelah melahirkan yang dilakukan di ruang bersalin (inisiasi dini). Menurut UNICEF dan WHO pada 6 bulan pertama bayi harus diberikan ASI eksklusif dan setelah 6 bulan keatas bayi dapat diberikan ASI dan makanan pendamping ASI sampai anak berumur minimal 2 tahun. Karena pada masa bayi 6 bulan keatas ASI sudah tidak mencukupi kebutuhan nutrisi pada bayi sehingga memerlukan MP-ASI yang berfungsi sebagai proses belajar mencerna makanan (Susanti and Rinawan 2018).

Pada ibu dengan latar belakang pendidikan yang beragam, maka perlu dibentuk kelompok KP-ASI untuk meningkatkan pemahaman tentang manajemen laktasi dan keterampilan terkait MP-ASI sehingga dapat memotivasi untuk memberikan ASI Eksklusif, MP ASI dan harapannya dapat meningkatkan cakupan ASI ekslusif dan meningkatkan keterampilan serta pengetahuan ibu dalam penyediaan MP-ASI untuk mendukung tumbuh kembang anak.

\section{Metode}

Metode yang digunakan untuk pelaksanaan kegiatan Pengabdian Pada Masyarakat Terpadu ini adalah metode pemberdayaan masyarakat partisipatif dengan model Participatory Rural Apraissal yaitu suatu metode pendekatan dalam proses pemberdayaan dan peningkatan partisipasi masyarakat, yang tekanannya pada keterlibatan masyarakat dalam keseluruhan kegiatan yang dilaksanakan. Kegiatan yang dilakukan berupa sosialisasi, penyuluhan, pelatihan, pendampingan sekaligus evaluasi atau monitoring kegiatan. Adapun metode penyelesaian masalah ini berupa: a. Pengenalan masalah/kebutuhan dan potensi serta penyadaran, pada tahap ini dilakukan identifikasi terhadap berbagai permasalahan yang dihadapi mitra.

Metode untuk melakukan identifikasi adalah dengan observasi dan wawancara dengan pihak-pihak terkait yaitu Koordinator KIA Puskesmas Tempuran, Kepala Desa Sidoagung, kelompok mitra yaitu bidan desa dan Kader Kesehatan Desa Sidoagung. b. Perumusan masalah dan penetapan prioritas, adapun masalah yang ditemukan di desa Sidoagung terkait dengan masalah ASI yaitu: terdapat 12 posyandu yang aktif melakukan kegiatan setiap bulan sekali, namun tidak fokus pada masalah ASI dan MP-ASI, terdapat 114 ibu menyusui, namun hanya 72 yang memberikan ASI Eksklusif (presentase sebanyak 63,2\%), belum adanya kelompok pendukung ASI (KP-ASI) sebagai wadah untuk mendukung suksesnya ASI Eksklusif dan MP-ASI. Prioritas permasalahan yang diangkat adalah tentang peningkatan cakupan ASI Eksklusif dan keterampilan dalam pembuatan MP-ASI. Oleh karena itu kemudian dilakukan musyawarah dan ditentukan solusi dari permasalahan ini. c. Perencanaan penerapan gagasan dan penyajian rencana kegiatan. Adapun kegiatan yang dilakukan adalah sosialisasi kegiatan pada seluruh unsur desa yang terkait, pembentukan struktur KP-ASI, pelatihan Manajemen Laktasi, pendampingan kader praktek keterampilan manajemen laktasi di Posyandu, pelatihan keterampilan MP-ASI, pendampingan kader di Posyandu praktek keterampilan MP-ASI, evaluasi atau monitoring kegiatan melalui lomba manajemen laktasi dan MP-ASI antar kader sebagai 
10 | Celebes Abdimas: Jurnal Pengabdian Kepada Masyarakat

bentuk evaluasi.

\section{Hasil Dan Pembahasan}

1. Sosialisasi Kegiatan pada seluruh unsur desa yang terkait

Sosialisasi kegiatan dilakukan pada awal pertemuan dengan kepala desa, bidan desa, kader posyandu yang mewakili seluruh dusun. Pada kesempatan ini dibahas maksud dan tujuan kegiatan ini, sekaligus melakukan FGD terkait prioritas masalah serta rencana yang akan dilakukan selama program berjalan. Kagiatan ini menghasilkan kesepakata rencana kegiatan yanga akan dilakukan bersama.
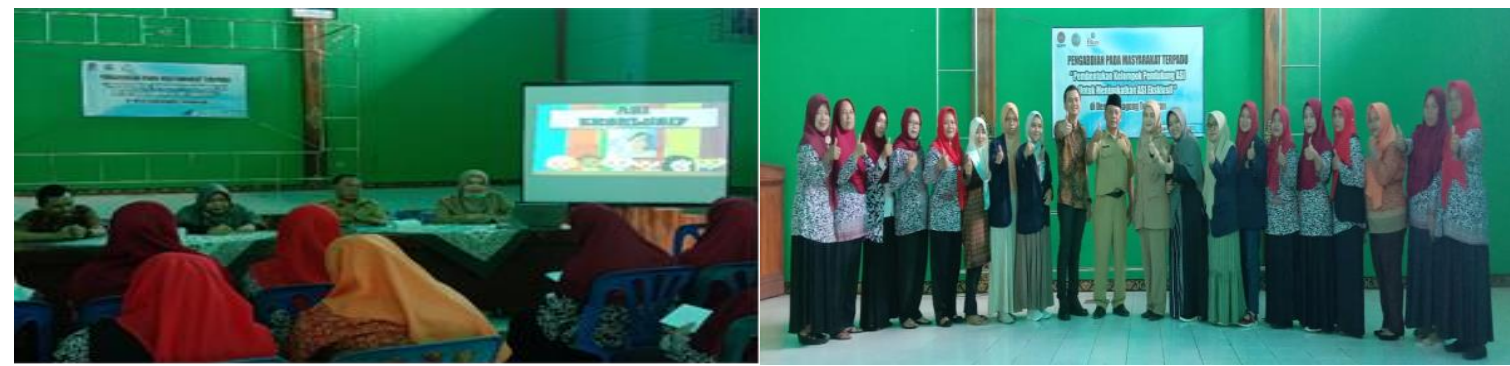

Gambar 1. Kegiatan Sosialisasi dan FGD dengan pemangku kepentingan

2. Pembentukan Kelompok Pendukung ASI Desa Sidoagung

Pembentukan KP-ASI ini diinisiasi oleh bidan desa dan di buat surat keputusan oleh Kepala Desa Sidoagung, dengan total pengurus sebanyak 10 orang. Pengurus dalam KP ASI terdiri dari bidan desa, beserta kader posyandu yang mewakili 12 posyandu. Kegiatan ini berupa reorganisasi karena SK sudah ada namun tidak ada satupun kegiatan yang dijalankan.

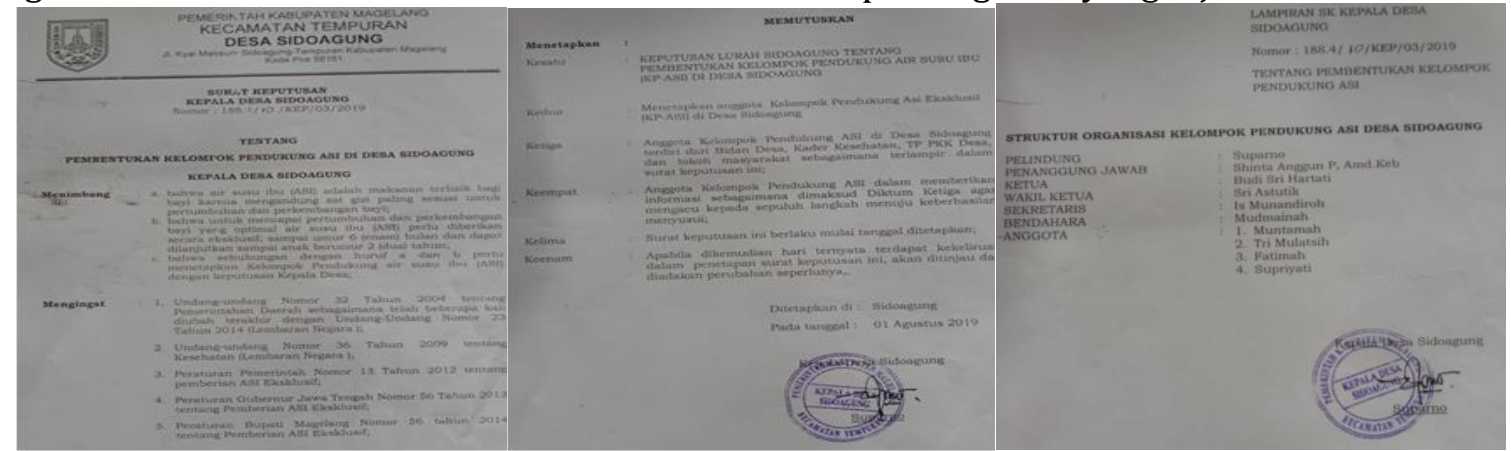

Gambar 2. SK Pembentukan Kelompok Pendukung ASI (KP-ASI)

Pembentukan KP-ASI atau istilah lainnya BPS (Breastfeeding Peer Support) ini penting untuk dibentuk terlebih dahulu struktur organisasinya, agar ada yang bertanggungjawab merencanakan, melaksanakan, memonitoring dan mengevaluasi kegiatan sesuai tujuan. Berdasarkan penelitian Putu, terbukti bahwa ada pengaruh BPS (Breastfeeding Peer Support) terhadap perilaku ibu dalam menyusui. Adanya perubahan perilaku ibu menyusui disebabkan oleh dukungan dan motivasi yang diberikan BPS, dimana hal ini juga dipengaruhi oleh dukungan budaya sekitar ibu dan pengalaman ibu dalam menyusui (Putu, Mertaningsih, Ketut, Prapti, \& Manangkot, 2017). Oleh karena itu langkah awal yang harus dilakukan adalah membentuk kelompok pendukung ASI agar dapat membuat gerakan dan menggerakkan masyarakat.

3. Pelatihan Manajemen Laktasi

Pelatihan manajemen laktasi ini dilaksanakan berdasarkan hasil Forum Group Discussion, dilaksanakan selama minggu pertama di Balai Desa Sidoagung. Kegiatan ini melibatkan kader posyandu dari 12 dusun dimana setiap dusun terdapat 3-5 kader yang terpilih. Metode pembelajaran dengan diskusi dan demonstrasi. Peserta mendapatkan modul pelatihan manajemen laktasi yang telah disiapkan tim pengabdian. Materi manajemen laktasi meliputi teori tentang ASI dan ASI Eksklusif, keterampilan teknik konseling laktasi, pelekatan pada 
payudara, posisi menyusui, cara menyusui yang benar, pijat oksitosin, breast care, cara memerah dan menyimpan ASI. Sebelum dan sesudah pelatihan diberikan pre dan post test untuk mengukur tingkat pengetahuan peserta dan menunjukkan bahwa ada peningkatan pengetahuan sebelum dan sesudah pelatihan.

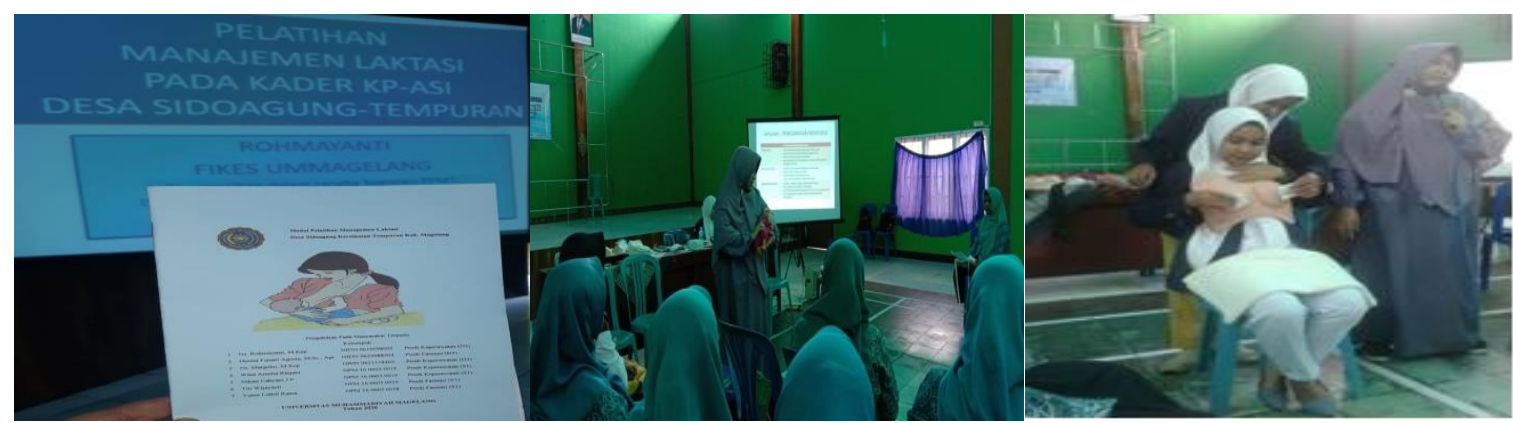

Gambar 3. Pelatihan Manajemen Laktasi dengan modul pelatihan dan demostrasi

Kegiatan ini bertujuan untuk meningkatkan pengetahuan dan keterampilan peserta untuk mendukung peningkatan cakupan ASI dan MP-ASI pada kader posyandu. Kegiatan ini diikuti oleh perwakilan dari seluruh posyandu di Desa Sumberagung yang meliputi 12 posyandu, jumlah peserta yang mengikuti sebanyak 35 orang.

Paired Samples Test

\begin{tabular}{|c|c|c|c|c|c|c|c|c|}
\hline & \multicolumn{5}{|c|}{ Paired Differences } & \multirow[b]{3}{*}{$t$} & \multirow[b]{3}{*}{$\mathrm{df}$} & \multirow[b]{3}{*}{ Sig. (2-tailed) } \\
\hline & \multirow[b]{2}{*}{ Mean } & \multirow[b]{2}{*}{ Std. Deviation } & \multirow{2}{*}{$\begin{array}{l}\text { Std. Error } \\
\text { Mean }\end{array}$} & \multicolumn{2}{|c|}{$\begin{array}{c}95 \% \text { Confidence Interval of the } \\
\text { Difference }\end{array}$} & & & \\
\hline & & & & Lower & Upper & & & \\
\hline Pair 1 pretest-postest & -3.17143 & 1.09774 & .18555 & -3.54852 & -2.79434 & -17.092 & 34 & .000 \\
\hline
\end{tabular}

Tabel.1 Peningkatan pengetahuan pre dan post pelatihan

Berdasarkan gambar 7 dapat dilihat bahwa terdapat perbedaan pengetahuan kader sebelum dan sesudah pemberian pelatihan menggunakan modul manajemen laktasi yang ditunjukkan dengan hasil uji paired test diperoleh nilai $p=0,00(<0,05)$. Hasil pretest dan postest mengalami perbedaan yang signifikan (berarti). Berdasarkan uji statistika pretest dan postest terbukti bahwa terjadi peningkatan skor tingkat pengetahuan kader setelah diberikan pelatihan dengan modul manajemen laktasi. Sehingga dapat ditarik kesimpulan bahwa pemberian pelatihan dan modul manajemen laktasi dapat meningkatkan pengetahuan kader KP-ASI di Desa Sidoagung. Hal ini sesuai dengan penelitian Yuniyanti bahwa keberadaan kelompok pendukung ASI eksklusif (KP-ASI) efektif terhadap perilaku pemberian ASI eksklusif ( $p$ value 0,0001) sehingga disarankan pada desa untuk menginisiasi agar masyarakat mau membentuk KP-ASI eksklusif di wilayah masing-masing dengan dukungan penuh dari bidan desa dan kader kesehatan setempat untuk memberikan dukungan pada ibu hamil dan ibu yang memiliki anak usia kurang dari dua tahun untuk memberikan ASI dan memberikan MP-ASI (Yuniyanti, 2017).

4. Pendampingan Kader atau anggota KP-ASI dalam praktek keterampilan manajemen laktasi

Setelah dilakukan pelatihan, maka kader wajib mempraktekkan ilmu yang telah didapatnya, para kader mendapatkan pendampingan dari tim pengabdian masyarakat untuk mengaplikasikan langsung ke ibu yang menyusui di Posyandu. Kegiatan Posyandu dilakukan pada tanggal ganjil mulai tanggal 15 setiap bulannya. 


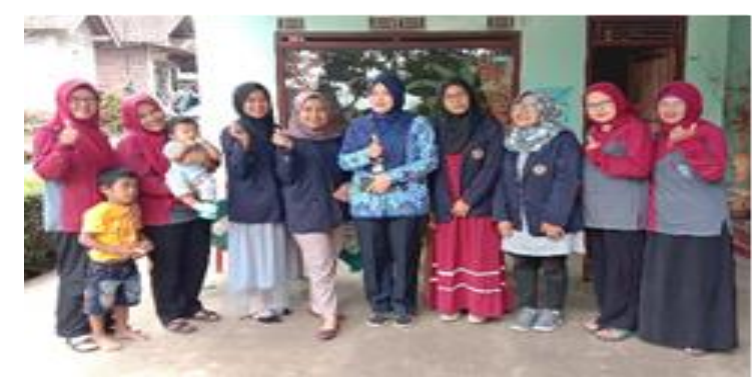

Gambar 4. Pendampingan kader di Posyandu

Pendampingan diperlukan untuk penguatan kegiatan dan menambah percaya diri kader. Hal ini sesuai dengan hasil penelitian bahwa pendamping peranannya penting dan dibutuhkan untuk pelaksanaan pemberdayaan masyarakat yang berkelanjutan mulai dari perencanaan, pelaksanaan, monitoring, evaluasi, kemitraan dan kemandirian. Pendamping kegiatan memerlukan koordinasi dan kerjasama untuk membentuk forum komunikasi serta kelompok kerja untuk melakukan kajian terhadap permasalahan, potensi dan prospek dalam pembangunan masyarakat desa (Weningsih, 2018).

\section{Pelatihan tentang Makanan Pendamping ASI (MP-ASI)}

Materi yang diberikan dalam pelatihan ini adalah: pengertian MP-ASI, kebutuhan energy pada anak, pemenuhan gizi bayi sesuai usia, tanda bayi siap di beri MP-ASI, waktu pemberian, jenis makanan, alasan pemberian MP-ASI, jadwal pemberian, tips pemberian MP-ASI dan contoh menu makanan sesuai usia, cara pemberian MP-ASI. Pemberian keterampilan pada kader berupa demo memasak menu MP-ASI usia 7-9 bulan dan usia 9-12 bulan. Hasil evaluasi berupa lomba pembuatan MP-ASI pada kader.

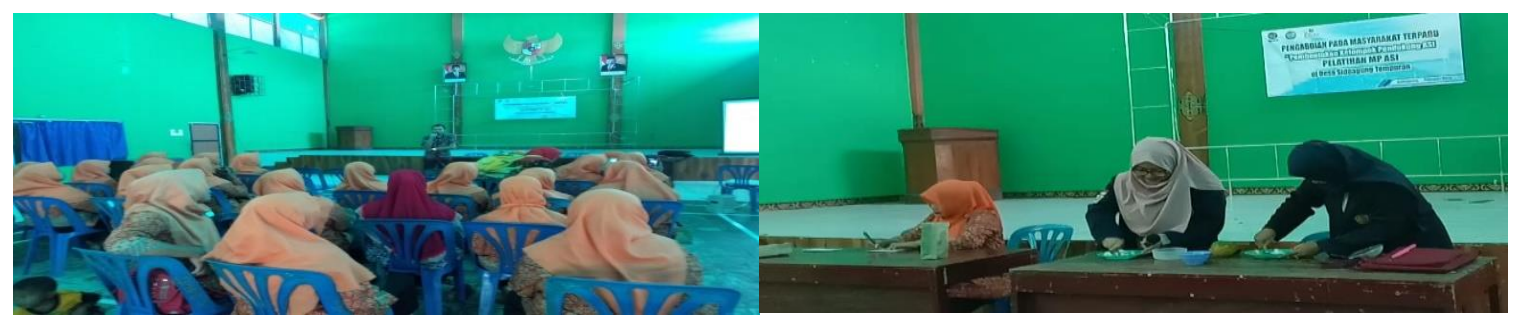

Gambar 5. Pelatihan MP-ASI dan demo pembuatan MP-ASI

Tujuan pembentukan kelompok pendukung ASI atau KP ASI ini sejalan dengan hasil program Pengabdian masyarakat yang dilakukan Nurlaila bahwa dengan terbentuknya kader PARAPAM (seperti KP-ASI) terbukti kader mampu melakukan pendidikan kesehatan dan mendampingi masyarakat dalam praktik menyusui dan pemberian MP-ASI dengan benar (Nurlaila et al., 2018). Pembentukan KP ASI ini tidak hanya untuk meningkatkan keterampilan dan dukungan dalam hal ASI Eksklusif saja, namun lebih luas sampai makanan pendamping ASI agar berkelanjutan. Meskipun demikian penelitian lain menunjukkan bahwa tidak ada satu jenis intervensi tunggal yang dapat mengatasi beberapa hambatan menyusui yang dihadapi oleh ibu. Strategi intervensi yang efektif memerlukan pendekatan bertingkat. Terdapat sebuah perspektif bahwa pengetahuan individu, perilaku, dan sikap yang dibentuk oleh interaksi antara wanita individu, teman dan keluarganya, dan pengalaman yang lebih luas, sosial, politik, ekonomi, kelembagaan, dalam konteks masyarakat. Oleh karena itu intervensi menyusui yang efektif harus mencerminkan semua aspek ini. Intervensi menyusui saat ini terkesan tidak ada kesinambungan dan tidak dapat memenuhi kebutuhan semua wanita secara sosial dan psikologis, sehingga perlunya pendekatan integratif untuk mengatasi kompleksitas pengalaman menyusui yang saling terkait dengan para ibu di seluruh lapisan masyarakat (Johnson, Kirk, Rosenblum, \& Muzik, 2015). Oleh karena itu salah satu yang dapat dilakukan adalah pembentukan Kelompok Pendukung ASI yang sangat membumi dengan masyarakat karena pendampingannya dilakukan oleh kader yang berasal dari masyarakat sendiri. 
6. Pendampingan Kader di Posyandu untuk pembuatan MP-ASI

Pendampingan kader setelah pelatihan MP-ASI dilakukan pada kegiatan Posyandu dengan mendampingi kader melakukan demo memasak di hadapan ibu-ibu yang masih menyusui anaknya agar dapat dijadikan contoh cara menyiapkan menu MP-ASI yang sehat.

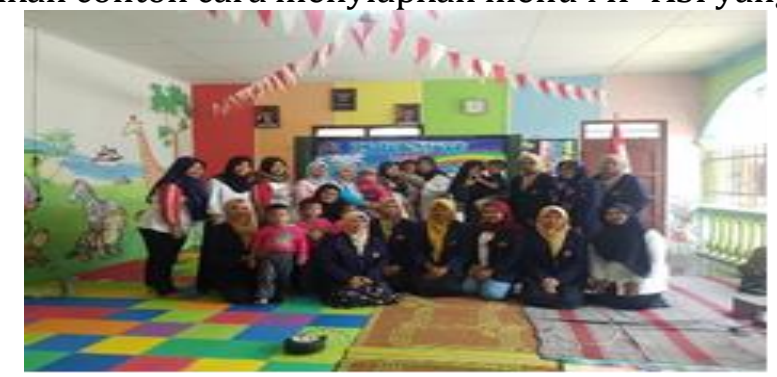

Gambar 6. Pendampingan kader KP-ASI di Posyandu

Tujuan pemberian MPASI untuk memenuhi kebutuhan gizi bayi, mengembangkan kemampuan bayi untuk menerima berbagai macam makanan dengan berbagai rasa dan tekstur yang pada akhirnya mampu menerima makanan keluarga, mengembangkan kemampuan bayi untuk mengunyah dan menelan (keterampilan oromotor) (Asosiasi Dietisien Indonesia, 2014), dan menanggulangi, mencegah terjadinya gizi buruk dan gizi kurang sekaligus mempertahankan status gizi baik pada bayi dan anak (Lestari, Lubis, and Pertiwi 2014). Bahan makanan yang dijadikan sebagai menu Makanan Pendamping ASI merupakan bahan yang mudah dilumatkan berupa kandungan gizi untuk pertumbuhan dan perkembangan anak usia 6-24 bulan berupa karbohidrat, protein, sayur-sayuran, vitamin, dan mineral serta penambahan pemberian buahbuahan yang mudah dilumatkan untuk mengenalkan tekstur yang halus kepada anak usia 6-24 bulan (Setyadi 2014).

7. Lomba antar kader KP-ASI sebagai bentuk evaluasi kegiatan

Kegiatan ini diutamakan untuk melakukan evaluasi pada kegiatan keterampilan pembuatan MP-ASI, dari 12 posyandu dilombakan setelah pelatihan dilaksanakan, dan didapatkan 3 kelompok pemenang yang berhasil menyajikan menu sehat, bergizi dan sesuai usia bayi, peserta yang telah berpartisipasi juga mendapatkan sertifikat pelatihan manajemen laktasi dan MP-ASI.

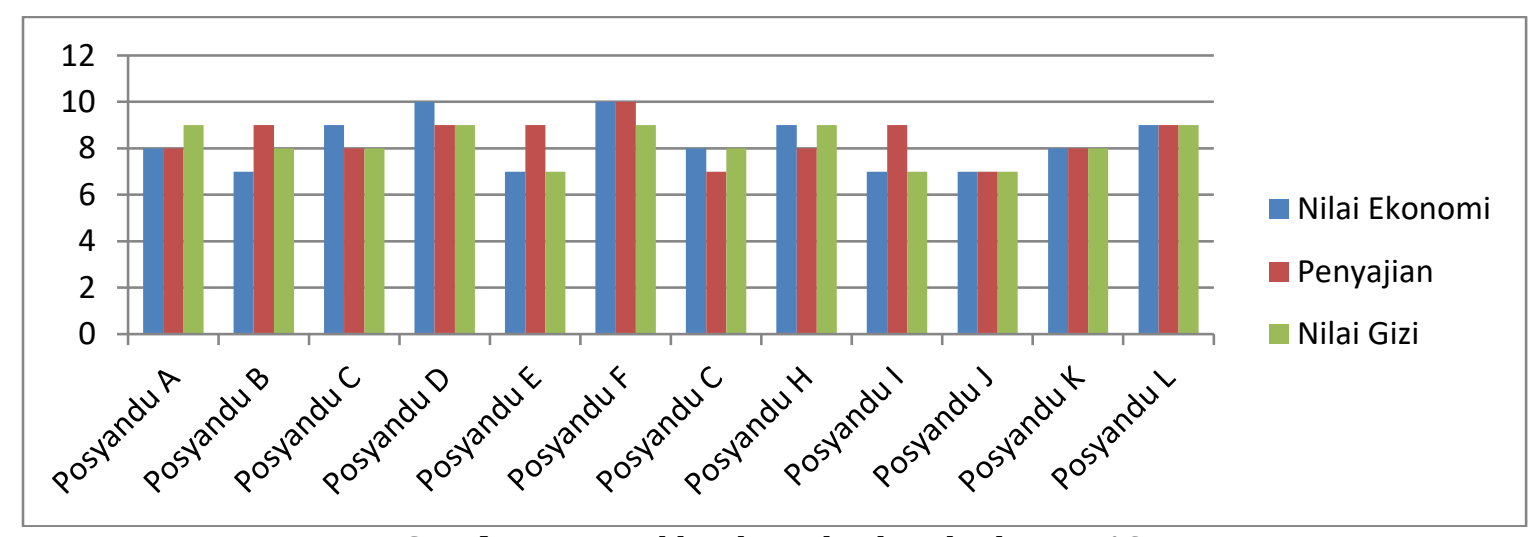

Gambar 7. Hasil lomba pelatihan kader KP-ASI

Dengan adanya kegiatan evaluasi ini maka diketahui apakah tujuan tercapai atau tidak, hasil kegiatan ini menunjukkan adanya peningkatan kemampuan keterampilan pembuatan MP-ASI oleh kader yang nantinya akan didesiminasikan pada masyarakat dilingkungannya. Pengetahuan dan keterampilan kader KP-ASI tentang MP-ASI juga meningkat, hal ini dilihat dari hasil lomba penyajian MP-ASI terlihat peserta antusias mengikuti. Makanan Pendukung ASI atau MPASI Makanan Pendamping ASI (MPASI) merupakan pemberian makanan atau nutrisi tambahan zat gizi untuk pertumbuhan dan perkembangan setelah ibu memberikan ASI ekslusif kepada anak usia 6-24 bulan serta bisa memperkenalkan anak dengan jenis makanan dengan bermacam tekstur dan rasa (Kemenkes RI). Makanan Pendamping ASI (MP-ASI) adalah makanan atau 
minuman selain ASI yang mengandung zat gizi yang diberikan kepada bayi selama periode penyapihan (complementary feeding) yaitu pada saat makanan/minuman lain diberikan bersama pemberian ASI (WHO) (Asosiasi Dietisien Indonesia, 2014). Makanan Pendamping ASI (MP-ASI) merupakan makanan peralihan dari ASI ke makanan keluarga. Pengenalan dan pemberian MP-ASI harus dilakukan secara bertahap baik bentuk maupun jumlahnya, sesuai dengan kemampuan bayi (Winarno. 1987, dalam Mufida, dkk. 2015).

Penelitian lain juga mengungkapkan bahwa di era digital sekarang ini, dukungan terhadap ibu menyusui dapat dilakukan melalui facebook, karena ibu muda sekarang banyak yang menggunakan media sosial ini dan mereka dapat berinteraksi melalui facebook dalam waktu yang lebih lama dan sesuai minat mereka (Robinson, Lauckner, Davis, Hall, \& Anderson, 2019). Oleh karena itu kedepannya berawal dari pembentukan KP-ASI ini nantinya dapat diinisiasi pembentukan kelompok pendukung ASI melalui facebook dengan grup tertutup supaya tetap ada privacy ketika membicarakan hal yang dianggap tabu. Seluruh hasil kegiatan ini menunjukkan bahwa penting untuk dilakukan pembentukan Kelompok Pedukung ASI guna meningkatkan cakupan pemberian ASI Ekskklusif dan pemberian MP-ASI bagi masyarakat dengan dibantu kader KP-ASI yang berasal dari mereka sendiri.

\section{Simpulan Dan Saran}

Hasil pengabdian pada masyarakat terpadu ini yaitu terbentuk kader Kelompok Pendukung ASI (KP-ASI) dengan pengurus sebanyak 10 orang. Pelatihan kader KP-ASI sejumlah 35 orang kader yang dilatih manajemen laktasi dan MP-ASI. Kader KP-ASI mampu melakukan konseling, pendidikan kesehatan dan mendampingi ibu yang kesulitan dalam praktek menyusui dan pemberian MP-ASI. Berdasarkan hasil pre dan post test kemudian di uji paired test diperoleh nilai $p=0,00(<0,05)$ dimana terdapat perbedaan yang signifikan (berarti), ini terbukti bahwa pemberian pelatihan dengan media modul manajemen laktasi serta praktek langsung dapat meningkatkan pengetahuan kader KP-ASI di Desa Sidoagung. Evaluasi dengan lomba demo menyiapkan MP ASI didapatkan hasil bahwa kader MP ASI mampu menyajikan MP ASI dengan benar. Berdasarkan data dari bidan desa didapatkan tedapat kenaikan cakupan ASI di Desa Sidoagung, Tempuran. Oeh karena itu ke depannya perlu ditindaklanjuti dengan monitoring hasil pelatihan kader agar dipraktekkan terus menerus pada masyarakat agar tercipta keberlangsungan program serta penggunaan media sosial seperti facebook untuk menjangkaumasyarakat lebih luas dan lama keberadaannya.

\section{Ucapan Terima Kasih}

Terimakasih kepada LP3M UMMagelang divisi Pengabmasy yang telah mendukung penuh kegiatan ini, dan kepada FIKES UMMagelang atas segala supportnya sehingga terlaksana kegiatan ini. Tidak lupa kepada kader Posyandu Desa Sidoagung, Bidan Desa dan kepala Desa Sidoagung atas partisipasi penuhnya sehingga terlaksana dengan baik seluruh kegiatan ini, serta mahasiswa peserta PPMT UMMagelang yang telah mengupayakan dengan maksimal dalam mendukung suksesnya kegiatan ini.

\section{Daftar Rujukan}

Dinas Kesehatan Kota Semarang. Profil Kesehatan Kota Semarang Tahun 2014. Semarang: Dinas Kesehatan Kota Semarang. 2014.

Dinas Kesehatan Kota Semarang. Profil Kesehatan Kota Semarang Tahun 2015. Semarang: Dinas Kesehatan Kota Semarang. 2015.

Dinas Kesehatan Kota Semarang. Profil Kesehatan Kota Semarang Tahun 2016. Semarang: Dinas Kesehatan Kota Semarang. 2016. 
Lestari, Mahaputri Ulva, Gustina Lubis, And Dian Pertiwi. 2014. "Hubungan Pemberian Makanan Pendamping Asi (Mp-Asi) Dengan Status Gizi Anak Usia 1-3 Tahun Di Kota Padang Tahun 2012." Jurnal Kesehatan Andalas 3(2): 188-90.

Rinata, Evi, Sm Faridah Hanum, And Tutik Rusdyati. 2016. "Ibm Kader Kesehatan Dalam Pembuatan Mp-Asi Di Desa Balong Tani Kecamatan Jabon Sidoarjo." Prosiding Rakernas Aipkema Teтu Ilmiah Hasil Penelitian Dan Pengabdian Masyarakat: 121-27. Https://Www.Neliti.Com/Id/Publications/175893/Ibm-Kader-Kesehatan-DalamPembuatan-Mp-Asi-Di-Desa-Balong-Tani-Kecamatan-Jabon-S.

Setyadi, Yanuri. 2014. "Penyusunan Menu Makanan Pengganti Asi Sebagai Intervensi Keperawatan An T Dengan Ketidakseimbangan Nutrisi Kurang Dari Kebutuhan Tubuh Di Kelurahan Sukatani Kecamatan Tapos Depok."

Susanti, Ari Indra, And Fedri Ruluwedrata Rinawan. 2018. "Optimalisasi Kegiatan Posyandu Dengan Pelatihan Kader Melalui Program Kuliah Kerja Nyata Mahasiswa ( Kknm ).” : 1-10.

Johnson, A., Kirk, R., Rosenblum, K. L., \& Muzik, M. (2015). Enhancing breastfeeding rates among African American women: A systematic review of current psychosocial interventions. Breastfeeding Medicine, 10(1), 45-62. https://doi.org/10.1089/bfm.2014.0023

Nurlaila, Riyanti, E., Setianingsih, E., Frastyo, Astriani, I., \& Juliana. (2018). Parapam Meningkatkan Pemberian ASI Eksklusif dan MP-ASI pada Bayi 0-12 Bulan. Proceeding of The 7th University Research Colloqium (URECOL) STIKES PKU Muhammadiyah Surakarta, 31-36.

Putu, N., Mertaningsih, I., Ketut, N., Prapti, G., \& Manangkot, M. V. (2017). PENGARUH BREASTFEEDING PEER SUPPORT TERHADAP PERILAKU IBU SELATAN PENDAHULUAN Angka kematian bayi di dunia diperkirakan mencapai empat juta per seribu kelahiran hidup tiap tahunnya . Hal ini disebabkan karena adanya infeksi penyakit yang menyerang sistem. COMMUNITY OF PUBLISHING IN NURSING (Coping), 5(April 2017), 34-43.

Robinson, A., Lauckner, C., Davis, M., Hall, J., \& Anderson, A. K. (2019). Facebook support for breastfeeding mothers: A comparison to offline support and associations with breastfeeding outcomes. Digital Health, 5, 1-12. https://doi.org/10.1177/2055207619853397

Weningsih, B. S. R. W. A. I. S. S. (2018). PERAN PENDAMPING DESA DALAM MODEL PEMBERDAYAAN MASYARAKAT BERKELANJUTAN. UNDIP Journal, 40-60.

Yuniyanti, B. (2017). Efektivitas Kelompok Pendukung Asi (Kp-Asi) Eksklusif Terhadap Perilaku Pemberian Asi Eksklusif. Jurnal Ilmiah Bidan, 2(1), 48-54. 